\title{
The effect of corporate governance and intellectual capital toward financial performance and firm value of socially responsible firms
}

\begin{abstract}
El efecto del gobierno corporativo y el capital intelectual sobre el desempeño financiero y el valor firme de las empresas socialmente responsables
\end{abstract}

\section{Robiyanto Robiyanto ${ }^{1,2^{*}}$, Adhi Rahadi Putra ${ }^{1}$, Andreas Lako ${ }^{2}$}

${ }^{1}$ Faculty of Economics and Business, Satya Wacana Christian University, Indonesia

${ }^{2}$ Doctoral Program in Environmental Science, Soegijapranata Catholic University, Indonesia

Received March 6, 2019; accepted November 11, 2019

Available online December 6, 2019

\begin{abstract}
The purpose of this study is to determine whether corporate governance (CG) and intellectual capital (IC) has an effect on the financial performance and firm value of socially responsible firms. The samples of this study were firms listed in the SRI (Socially Responsible Investment)-KEHATI Index in Indonesia Stock Exchange. This study found that CG and IC had a positive significant effect to the firm value with financial performance as the intervening variable. Further, CG and IC was found to have a direct positive significant effect on the firm value.
\end{abstract}

JEL codes: G30, Q50

Keywords: Corporate governance (CG); Intellectual capital (IC); Value added intellectual capital (VAIC); Financial performance; Firm value

*Corresponding author.

E-mail address: robiyanto@staff.uksw.edu (R. Robiyanto).

Peer Review under the responsibility of Universidad Nacional Autónoma de México. 


\section{Resumen}

El propósito de este estudio es determinar si el gobierno corporativo (GC) y el capital intelectual (CI) tienen un efecto sobre el desempeño financiero y el valor firme de las empresas socialmente responsables. Las muestras de este estudio fueron empresas que figuran en el índice SRI (inversión socialmente responsable) -KEHATI de la Bolsa de Valores de Indonesia. Este estudio encontró que CG e IC tuvieron un efecto positivo significativo en el valor de la empresa con el desempeño financiero como variable interviniente. Además, se encontró que CG e IC tenían un efecto significativo positivo directo sobre el valor de la empresa.

Código JEL: G30, Q50

Palabras clave: Gobierno corporativo (GC); Capital intelectual (CI); Capital intelectual de valor agregado (VAIC); Desempeño financiero; Valor firme

\section{Introduction}

Today's business world requires firm management to be more creative, resulting to the firm value to be maintained and even developed. The firm value is very important to be developed to increase the wealth of the investors and stakeholders. It can actually be reflected in the firm's shares. The higher the firm's stock price, the more the investors who trust the firm. A good firm value must be supported by the effectiveness of the firm in its financial performance (Gamayuni, 2015). There are various indicators that can be used to determine the firm effectiveness in managing their finances. These indicators are divided based on financial ratios, namely return on investment (ROI), return on assets (ROA), earnings per share (EPS), dividends per share, economic value added (EVA), market value added (MVA), the value of Tobin's Q (TQ), and operational efficiency's indicators.

The firm's financial effectiveness is certainly not only influenced by tangible assets, but also by intangible assets. Intangible assets are firm assets that are not visible and not recorded in the firm's financial statements but it might increase the firm's competitiveness. Intangible assets in question are corporate governance (CG) and intellectual capital (IC). According to Ganescu and Gangone (2012), the CG application of the firms is not only to increase the firm value, but also to make the corporate financial performance more effective (Handriani \& Robiyanto, 2018). This is because the implementation of CG in a firm indicates the mechanism creation to control and create an efficient system and corporate financial governance. The more efficient the firm is, the better the firms in the investors' perspective will be (Arifin, Suhadak, Astuti, \& Arifin, 2014).

According to Cantu, Bustani, Molina, and Moreira (2009), IC is a knowledge shared with all members of the firm that can provide added value and competitive advantage of the firm. 
Kamath (2015) argued that IC is the number of anything in the firm offering competitiveness in the market. The application of IC in the firm can help the firm in formulating and assessing whether the strategy implemented is appropriate or not, helping in making a decision to diversify and / or expand the firm, and it is a basis for providing compensation to the employees, and a means to communicate with external stakeholders (Marr, Gray, \& Neely, 2003).

Various studies have been conducted to examine the influence of CG, IC, corporate financial performance, and firm value. For example, the researches by Al-Musali and Ismail (2014); Hassan and Halbouni (2013); Komnenic and Pokrajcic (2012); Prusty and Kumar (2016); Vintila and Ghergina (2012). However, most of these studies only examined in one particular sector. To the best of our knowledge, there are no studies on firms that are socially responsible specifically. In Indonesia, there is a stock price index specifically classifying the socially responsible stocks. It is called SRI (Socially Responsible Investment) KEHATI Index which consists of 25 shares of firms that have met the category of the socially responsible firms. In addition, these firms are also considered to have a good corporate governance. The SRI KEHATI Index is an index that describes firms that do not only benefit economically but also pay attention to the environmental preservation around them (Lakaba \& Robiyanto, 2018; Utomo, Wahyudi, Muharam, \& Taolin, 2018; Wahyudi, Pangestuti, Laksana, Hersugondo, \& Robiyanto, 2018). The SRI KEHATI Index was formed to spread the information widely to the wider community, so that they would recognize the characteristics of firms that have environmental concerns, community involvement, human resources, corporate governance, human rights, and acceptable business ethics on international level (Zulkafli, Ahmad, \& M., 2017). Firms listed on the SRI KEHATI Index will have a total asset of more than one trillion, a free-floating rate of more than ten percent, a positive price earnings ratio, a good corporate governance, business ethics, adequate human resources, justified human rights, and etc. which are also the conditions of the SRI KEHATI Index (Robiyanto, 2018).

This study specifically examines the direct and indirect effects of CG and IC on firm value by using financial performance as an intervening variable. The research was also carried out using CG indices calculated by leading independent institutions such as the CGPI and the ASEAN CG Scorecard for most researches on CG mostly used the CG proxies such as the number of independent commissioners and board of commissioners and directors' size which is not a comprehensive measurement of $\mathrm{CG}$ activities in a firm.

The research problem of this study is how the CG and IC on the firm value with the corporate financial performance as the intervening variable give an effect in socially responsible firms. Therefore, the purpose of this study is to understand the effect of CG and IC on the firm value with the corporate financial performance as the intervening variable in socially responsible firms. 


\section{Literature review and hypotheses}

Stakeholder Theory, Agency Theory and Resource-based Theory

According to Stakeholder Theory, a company is not just looking for a profit, but also must provide benefits for stakeholders (Suhardjanto, Purwanto, Sari, \& Setiany, 2018). The Stakeholder Theory also been related with some prominent theories in the management field such as Agency Theory, Slack-resources Theory, and Resources-based Theory (Melo, 2012a). Agency theory focuses on the agency problems that occur between the principal and firm agents and it tries to explain the conflict of interest between the principal and the agents (Ehikioya, 2009). This concept appears to be able to mediate the existed agency problems. CG is defined as a system for directing and controlling a business in operation (Handriani \& Robiyanto, 2019; Jaffar, Aziendeh, Shukor, \& Rahman, 2018).

The characteristics of CG are responsibility, accountability, fairness and transparency. The clearer role and function of the CG system will help the firm to attract investors. While, Resource-based view (RBV) focuses on the firm-owned resources as a fundamental determinant of the competitive advantages and firm performance (Flore, 2000). The RBV adopts two assumptions in analyzing the sources of competitive advantages. The first assumption is that industrial firms are very diverse and they respect each other's resources. The second is that these diverse resources enable the company to survive from time to time because the strategies applied to the firm are not comprehensive. The diversity in the firm is needed to improve the firm's competitive advantages. However, this does not apply to all firms. RBV is such an explanation of efficiency of a firm performance. RBV Theory has been researched regarding corporate financial performance and corporate social (Melo, 2012b). The RBV can be related with innovation, which is very crucial for business (Ueasangkomsate \& Jangkot, 2017). In the next section some related concept such as firm value, corporate financial performance, corporate governance, and intellectual capital will be discussed.

\section{Firm Value}

Firm value is a perception created by investors towards a firm which is always associated with the company's performance in the market which is reflected in the firm's stock price (Nuryaman, 2015). The firm value will not only increase because of its ability to maximize profits, but also if it puts a concern on the social environment and the society. The firm value can be measured by using Tobin's Q (Handriani \& Robiyanto, 2018).

Tobin's $Q$ is a market value of a firm or it can be considered as a book value of a firm. The Tobin's Q ratio can be calculated by comparing the ratio of the market value equity (MVE) with the book value equity (BVE) of the firm. The MVE can be obtained from the results of the multiplication of stock prices at the end of the year with the total number of outstanding 
shares at the end of the year. The BVE can be obtained by the difference between the total assets of the firm and its total liabilities. Tobin's $Q$ is used to measure the market value of a firm's stock. If the Tobin's Q is less than one, it is considered that the firm is undervalued or the firm's value in the market is smaller than the book value. This condition will attract and increase the investors' interest to buy the firm shares because prefer to buy the firm's assets at a cheaper price compared to when the firm's assets are resold. Conversely, if the Tobin's $\mathrm{Q}$ is more than one, it can be considered that the firm is overvalued or the firm's value in the market is greater than the book value. This condition indicates that the firm has a high growth potential.

\section{Corporate financial performance}

Performance is an action to achieve goals which can be measured by various types of benchmarks and it is the result of what is done by managers of an organization to maximize their duties and responsibilities. Firm performance is the result of various decisions taken in the firm management. In today's competitive world, creating value for shareholder wealth is the main goal of the firm. The investors who always want to increase their wealth maximally will see the opportunity to invest in potential firms. The most important thing in today's business line is maximizing shareholder wealth. Therefore, it is important for the firms to be formulate their financial strategies to create maximum financial performance of the firm (Hossein \& Zivar, 2014).

The indicators used to measure or to find out the corporate financial performance in this study were the EPS and ROE. The EPS was used because its ratio shows how much profit per share the investors could get when they invest their funds. The ROE was used to find out the financial efficiency of the firm.

\section{Corporate Governance}

Adeusi, Akeke, Aribaba, and Adebisi (2013) explained that CG is a set of rules that can control and direct a firm. CG implementation aims to ensure that the business runs well and they investors could get the appropriate and deserving return (Brahmana, Brahmana, \& Ho, 2018; Kuo, Kao, \& Sakolvieng, 2019). Firms that implement CG well indicates that they have a good intention, transparency, responsibility and accountability that aim to maximize their shareholders' wealth (Robiyanto, Anggraeni, Nugraha, \& Lako, 2019). Onakoya, Ofoegbu, and Fasanya (2012) added that CG is an important concept that is highly related to the procedures and manner of a firm with the existing resources - human, machine or financial resources - which can effectively be used to achieve a good firm value. Although there are many opinions expressed by the experts from previous studies, it can still be concluded that the application of CG aims to ensure the welfare of the owners of the firm. 
In this study, the proxies used to assess the CG are the score of the Corporate Governance Perception Index (CGPI), the ASEAN Corporate Governance Scorecard (ACGS), and the Financial and Development Supervisory Agency (FDSA). The CGPI, ACGS and FDSA are the results of assessments in the form of numbers that can represent the $\mathrm{CG}$ implementation in a firm based on the assessment of the principles of CG, commitment, leadership, strategy, vision, mission, ethics, culture, and values of a firm. The use of CGPI, ACGS, and FDSA will produce a more reliable and accurate assessment of the CG of a firm.

\section{Intellectual Capital}

IC is an intellectual material formalized, managed and obtained to produce high value assets. IC consists of any important sources of knowledge to produce firm value, but are not listed in the firm finance. This indicates that the IC consists of knowledge, experience, firm technology, relationships with customers, suppliers and etc. that can create competitive advantages in the market (Hossein \& Zivar, 2014). The IC concepts include inventions, ideas, general knowledge, design approaches, computer programs and publications (Khanqah, Khosroshahi, \& Ghanavati, 2012). The IC also can boost the value creation to stockholder through innovation (Patthirasinsiri \& Wiboonrat, 2017).

Pulic (2000) developed an easy method to calculate the IC. He further argued that the market value of organizations was formed with the workers and the ICs. The method used is to facilitate in providing information from the efficiency value of intangible and tangible assets of the organization. This method is known as Value Added Intellectual Coefficient (VAIC), which indirectly measures the IC through the Capital Employed Efficiency (VACA), Human Capital Efficiency, and Structural Capital Efficiency (VAHU). The higher the value of VAIC, the better the use of value and the creation of potential firms.

\section{Research Hypotheses}

The Effect of CG on Corporate financial performance

Paul (2015) examined the relationship between the CG and the corporate financial performance in microfinance banks in Nigeria. The results of the study showed that there was a significant influence between the $\mathrm{CG}$ and the corporate financial performance. The study emphasized that the better the CG implementation, the more the firm's effectiveness in managing the firm.

A good implementation of CG could prevent firms from bankruptcy, corporate scandals, mistakes in managing the firm and so on. Therefore, the implementation of a good CG enables the firm to survive, even in difficult conditions. A research conducted by Abdulazeez and Mercy (2016) at 15 banks in Nigeria showed that a large corporate structure had a better firm 
performance than a small firm structure. This happened as when a firm had a large corporate structure, it was difficult for someone (in this case: the firm CEO) to regulate the firm and that the decision making would also be based on mandate, consideration from various parties and not from the individual wishes. The results of this study also claimed that the non-executive directors worked and served wholeheartedly and this was included in the CG code specifications. In addition, Nahar, Jubb, and Azim (2016) had examined 30 banks in Bangladesh with 7 years of research period which was from 2006 to 2012 . The study showed that the CG could affect the financial performance of the banks in Bangladesh positively and significantly.

In a study conducted by Orazalin, Mahmood, and Lee (2016), it was proved that in an economic crisis in Russia, the banks increased the CG of their respective firms and the results showed that although they were in an economic crisis, the firms with a good CG still survived and did not experience bankruptcy. Some studies conducted by Aras, Aybars, and Kutlu (2010); Bastomi, Salim, and Aisjah (2017); Mai (2017); Orazalin et al. (2016); Suhardjanto et al. (2018), also found that CG has a positive effect on corporate financial performance. Based on this reason, the hypothesis that can be proposed is as follows:

$\mathrm{H}_{1}$ : CG has a positive effect on the corporate financial performance

\section{The Effect of CG on Firm Value}

Al-Najjar (2018); Handriani and Robiyanto (2019) examined the effect of CG on firm value with the board of commissioners, independent board of commissioners, and audit committee as the indicators. The results revealed that they both partially and simultaneously had a positive effect. This happened because they had the obligation to supervise the firm's performance. With this supervision, the CG practice would be better for the firm.

Another research was conducted by Adefemi, Hassan, and Fletcher (2018); Tuan and Tuan (2016). They confirmed that simultaneous implementation of GCG, the application of managerial and institutional ownership, and a good implementation of independent board of commissioners influenced the firm value. It was explained in the study that with the implementation of a good CG, it would create a good corporate mechanism. This would make the managers to manage the firm under the supervision of the firm owners, resulting to an impact on the firm value which led to the desired profits obtained by the investors.

Bhat, Chen, Jebran, and Bhutto (2018) examined the effect of CG on firm value by using task boards, executive compensation, board size, and board independence as the indicators. The results mentioned that the CG simultaneously influenced the firm value. These results were in line with the research results by Andriana and Panggabean (2017); Bhat et al. (2018); Isshaq, Bokpin, and Onumah (2009); Mai (2010); Robiyanto et al. (2019); Siminica, Ionascu, and Sichigea (2019) which showed that the CG affected the firm value. Thus, it could be concluded that the CG was an influential factor of the firm value. For this reason, the formu- 
lated hypothesis is as follows:

$\mathrm{H}_{2}$ : CG has a positive effect on firm value

\section{The Effect of IC on Corporate financial performance}

Theoretically, by using the RBV, previous researchers stated that IC is the driver of the value of each firm. IC is also the core of every competitive advantage. On the other hand, empirical evidence could not be concluded as a whole. As explained earlier, IC is an asset that is not visible but has added value to the firm. If the assets in the firm can be managed properly, then the corporate financial performance will increase and the firm has added value as the firm's competitive advantage to compete with its competitors (Cater \& Cater, 2009; Patthirasinsiri \& Wiboonrat, 2017).

The VAIC approach was adopted by Riahi $\square$ Belkaoui (2003) who examined the influence of IC and the corporate financial performance on multinational firms in the USA. The results showed that there was a significant influence between the IC and the corporate financial performance. It was also explained that the application of a good IC would make the firm to have resources that could survive in difficult conditions and it was one of the supporters of the firm's wealth. This was in line with a research conducted by Isshaq et al. (2009); Riahi $\square$ Belkaoui (2003) saying that IC could develop the corporate financial performance. This happened because IC could make the existing resources in the firm to be more qualified in managing the firm, resulting it achieved the firm's goals which was to increase the firm's profits and shareholder wealth. Some studies i.e. Fathi, Farahmand, and Khorasani (2013); Kamukama, Ahiauzu, and Ntayi (2010); Ousama and Fatima (2015); Sidharta and Affandi (2016) found that the IC has a positive effect on the corporate financial performance. Therefore, the hypothesis that can be formulated is as follows:

$\mathrm{H}_{3}$ : IC has a positive effect on the corporate financial performance

\section{The Effect of IC on Firm Value}

A good arrangement of intellectual resources can increase the firm's market value. If three intellectual sources - capital, human capital and structural capital - can be managed properly, then this will create a great IC in the firm. The IC will facilitate the firm to excel in meeting the interests of all stakeholders, including investors. Investors in the capital market will appreciate the greatness of the IC owned by a particular firm with an increased demand for shares of the firm. In addition, if this happens, it will result in an increase in the firm value.

Suparno and Ramadini (2017) had previously proven that IC had a positive influence on the firm value with VAIC as the indicator of the measurement. The study showed that the better the IC, the more value the firm would have and led them to survive in difficult circumstances. In these difficult circumstances, the firms with added value could survive and avoid 
bankruptcy. Another study conducted by Chen, Cheng, and Hwang (2005) confirmed that a good IC could help firms to formulate corporate strategies, making them possible to compete with other firms or to overcome existed problems. Thus, the firm could still optimize the wealth of the shareholders as expected. Anifowose, Abdul Rashid, and Annuar (2017); Sardo and Serrasqueiro (2017)'s finding also support this statement. Therefore, the hypothesis can be formulated as follows:

$\mathrm{H}_{4}$ : IC has a positive effect on firm value

\section{The Effect of Corporate financial performance on Firm Value}

Basically, financial performance is one of the fundamental aspects of the assessment of the firm condition. In investing, the investors will consider several things related to the information that can be used to make investment decisions. One of them is the financial performance. Meanwhile, according to Andriana and Panggabean (2017); Mukhtaruddin, Relasari, and Felmania (2014), investors always make an overview of a firm by looking at its financial ratios as the material for evaluating investments as financial ratios can reflect the high or low value of the firm. This financial performance measurement is one of the indicators used by investors which can be seen directly at the stock market prices on the stock exchange. The better the corporate financial performance, the higher the return that investors will get.

A research conducted by Handriani and Robiyanto (2018) which used ROE as one of the financial ratios and its effect on firm value suggested that ROE had a positive effect on firm value. While, Marlina (2013) examined her research by using earning per share (EPS) as the financial ratio on firm value. Her results showed that EPS had a significant positive effect on firm value. Based on this reason, the hypothesis can be formulated as follows:

$\mathrm{H}_{5}$ : Corporate financial performance has a positive effect on firm value.

\section{Research method}

Data

This study used secondary data, namely the firm's annual financial statements obtained from www.idx.co.id.

\section{Population and Sample}

The population used in this study were 25 firms listed in the SRI-Kehati Index. The sampling technique used was purposive sampling which was done by selecting which firms met these following criteria:

1. Firms listed on the SRI-Kehati Index for the period of 2018;

2. Firms that consistently records their GCG assessment scores in the annual reports 
of 2013-2017.

Therefore, out of a total 25 firms which had met the first criteria, there were only 10 firms which had met the second criteria. They were PT Adhi Karya (Persero) Tbk. (ADHI), PT Bank Negara Indonesia Tbk. (BBNI), PT Bank Rakyat Indonesia Tbk. (BBRI), PT Bank Mandiri Tbk. (BMRI), PT Timah Tbk. (TINS), PT Telekomunikasi Indonesia Tbk. (TLKM), PT Semen Indonesia (Persero) Tbk. (SMGR), PT Perusahaan Gas Negara (Persero) Tbk (PGAS), PT Wijaya Karya (Persero) Tbk. (WIKA) and PT Waskita Karya (Persero) Tbk (WSKT). This study would examine these firms for 5 years, starting from 2013 to 2017. Thus, there were 50 observations in this study. The observations number in this study is met Hair, Black, Babin, and Anderson (2009)'s 10-times rule. Kock (2018); Kock and Hadaya (2018) stated that this assumption "builds on the assumption that the sample size should be greater than 10 times the maximum number of inner or outer model links pointing at any latent variable in the model". This study using four latent variables, so based on this rule, the minimum observation size is 40 .

\section{Operational Definition}

The following is a description of the variables in the study:

Corporate Governance.Good Corporate Governance (GCG) is a system that regulates and controls related firms to be able to increase their firm value for the shareholders. The GCG mechanism is such an ownership of the firm itself. Thus, the CG in this study was measured by the CGPI (Corporate Governance Perception Index), FDSA (Financial and Development. Supervisory Agency), and ACGS (ASEAN Corporate Governance Scorecard). The CGPI, FDSA, and ACGS used in this study because these are the standard measurement in Indonesia and also in ASEAN (ACGS). These measurements been widely accepted in those regions.

Intellectual Capital. IC is an intangible firm asset that can be managed, so that it can increase the firm value. IC measurement method used Value Added Intellectual Capital (VAIC) as what had been used by Hermawan and Herlina (2013).

Corporate financial performance. Firm performance can be measured from its financial performance and in this study, it was proxied on the financial ratios such as Return on Equity (ROE) and Earning Per Share (EPS).

Firm Value. The proxy used to measure the firm value was Tobin's Q. If the Tobin's Q value is more than 1 , then it can be concluded that the firm has a large competitive advantage, resulting to the opportunity to invest in the firm to be also large (Ratri \& Dewi, 2017). The following is a formula of Tobin's Q:

Tobin's $\mathrm{Q}=\frac{(\text { OS } X P)+(D+I)-C A}{T A}$ 
Where:

Tobin's $\mathrm{Q}=$ Firm value

OS = Outstanding Shares

$\mathrm{P}=$ Stock Price

$\mathrm{D}=$ Total Debt of Firm

$\mathrm{I}=$ Total Inventory

$\mathrm{CA}=$ Current Assets

$\mathrm{TA}=$ Total Assets

\section{Analysis Technique}

This study used Partial Least Square (PLS) analysis techniques with Smart PLS to examine the hypotheses from the existing relationships between variables. Structural Equation Modeling based on cross-lagged analysis was used to assess the existing model. Steps taken in cross-lagged analysis were based on the panel data collected more than once. The steps of this cross-lagged analysis were done to draw conclusions about the causal relationship in the data from a longitudinal research. This study used annual time series data from the beginning of January 2013 to the end of December 2017.

\section{Results and discussion}

\section{Descriptive Statistical Result}

Descriptive Statistical Result of Corporate Governance

The following Table 1. is the CG data using the CGPI, ACGS and FDSA indicators of the firms used in this study in the period of 2013-2017.

\section{Table 1}

Descriptive Statistical Result of Corporate Governance

\begin{tabular}{ccccccccc}
\hline No. & Firm Code & \multicolumn{9}{c}{ Year } & \multicolumn{3}{c}{ Mean } & STDEV \\
& & 2013 & 2014 & 2015 & 2016 & 2017 & & \\
\hline 1 & ADHI & 89.500 & 85.300 & 77.710 & 83.410 & 81.630 & 83.510 & 4.367 \\
2 & BBRI & 85.560 & 86.430 & 86.920 & 87.740 & 88.480 & 87.026 & 1.134 \\
3 & BBNI & 87.190 & 87.460 & 87.730 & 88.360 & 88.600 & 87.868 & 0.596 \\
4 & BMRI & 91.880 & 92.360 & 92.880 & 93.290 & 93.320 & 92.746 & 0.621 \\
5 & TLKM & 90.660 & 90.660 & 91.180 & 91.180 & 91.200 & 90.976 & 0.289 \\
6 & SMGR & 84.580 & 91.380 & 93.310 & 92.230 & 93.370 & 90.974 & 3.668
\end{tabular}




\begin{tabular}{ccccccccc}
7 & PGAS & 91.620 & 92.060 & 92.140 & 93.940 & 94.610 & 92.874 & 1.316 \\
8 & TINS & 75.100 & 75.670 & 85.110 & 87.278 & 90.345 & 82.701 & 6.935 \\
9 & WIKA & 86.070 & 89.230 & 93.350 & 94.930 & 94.930 & 91.702 & 3.917 \\
10 & WSKT & 83.900 & 85.030 & 86.440 & 86.440 & 88.240 & 86.010 & 1.640 \\
& MIN & & & & & & 82.701 & 0.289 \\
& MAX & & & & & 92.874 & 6.935 \\
\hline
\end{tabular}

Source: Annual Financial Reports, processed.

Based on the data in Table 1. above, it can be concluded that in the period of 2013-2017, National Gas Firm (Persero) Tbk. (PGAS) has an average CG value of 92.874, or in other words, it had the best CG implementation. In addition, in the period of 2013-2017, PT Timah Tbk. (TINS) has an average CG value of 82.701 and it can be concluded that it had the worst CG implementation. Further, Table 1. also presents the standard deviation (STDEV) obtained by PT Telekomunikasi Indonesia Tbk. (TLKM) of 0.289 which is the smallest standard deviation and it indicates that the spread of TLKM data was the narrowest compared to other firms. The biggest standard deviation is obtained by PT Timah Tbk. (TINS) which has a value of 6.935. This explains that the spread of TINS data was the widest among other firms.

\section{Descriptive Statistical Result of Intellectual Capital}

The IC data which used Value Added Intellectual Capital (VAIC) of the firms in the period of 2013-2017 is presented in the following Table 2. Based on the data from Table 2., it can be seen that Wijaya Karya (Persero) Tbk. (WIKA) has an average value of 3.850 which shows that it had the best IC compared to other firms used in this study. Conversely, the lowest IC is obtained by PT Telekomunikasi Indonesia Tbk. (TLKM) which has an average IC value of 1.406 .

Table 2

Descriptive Statistical Result of Intellectual Capital

\begin{tabular}{|c|c|c|c|c|c|c|c|c|}
\hline \multirow[t]{2}{*}{ No. } & \multirow{2}{*}{$\begin{array}{l}\text { Firm } \\
\text { Code }\end{array}$} & \multicolumn{4}{|c|}{ VAIC Value } & \multirow[b]{2}{*}{2017} & \multirow[t]{2}{*}{ MEAN } & \multirow[t]{2}{*}{ STDEV } \\
\hline & & 2013 & 2014 & 2015 & 2016 & & & \\
\hline 1 & ADHI & 3.574 & 4.474 & 3.117 & 3.092 & 3.442 & 3.540 & 0.562 \\
\hline 2 & BBRI & 2.534 & 2.475 & 2.393 & 2.403 & 2.437 & 2.448 & 0.058 \\
\hline 3 & BBNI & 1.592 & 1.724 & 1.953 & 1.970 & 1.923 & 1.832 & 0.167 \\
\hline 4 & BMRI & 1.913 & 1.940 & 1.275 & 2.104 & 1.872 & 1.821 & 0.318 \\
\hline 5 & TLKM & 1.431 & 1.428 & 1.422 & 1.429 & 1.322 & 1.406 & 0.047 \\
\hline
\end{tabular}




\begin{tabular}{ccccccccc}
6 & SMGR & 3.708 & 3.522 & 3.322 & 4.808 & 1.954 & 3.463 & 1.021 \\
7 & PGAS & 3.911 & 3.940 & 3.158 & 2.634 & 2.497 & 3.228 & 0.683 \\
8 & TINS & 2.986 & 3.251 & 1.644 & 2.104 & 2.190 & 2.435 & 0.664 \\
9 & WIKA & 4.426 & 4.434 & 4.681 & 3.105 & 2.606 & 3.850 & 0.931 \\
10 & WSKT & 1.616 & 1.422 & 1.262 & 1.533 & 3.773 & 1.921 & 1.044 \\
& MIN & & & & & & 1.406 & 0.047 \\
& MAX & & & & & & 3.850 & 1.044 \\
\hline
\end{tabular}

Source: Summary of Firm Financial Statements, processed.

Further, Table 2. also presents the smallest standard deviation (STDEV) of 0.047 which is obtained PT Telekomunikasi Indonesia Tbk. (TLKM). This shows that it had the narrowest spread of IC data compared to other samples. While the biggest STDEV is obtained by PT Bank Negara Indonesia Tbk. (BBNI) which is equal to 0.167 and it shows that it had the widest spread of data compared to other samples.

\section{Descriptive Statistical Result of Corporate financial performance}

The indicators used to measure a corporate financial performance were EPS and ROE. Table 3. shows the descriptive statistical results of EPS from each firm used in this study in the period of 2013-2017. Meanwhile Table 4. shows the descriptive statistical results of the ROE.The corporate financial performance data was obtained from a summary of the firm financial statements at www.idx.co.id. Based on the data from Table 3., it can be concluded that PT Bank Rakyat Indonesia Tbk. (BBRI) has the highest EPS value of Rp 1,059.21. This explains that BBRI was the firm that shared the largest profits with shareholders, reaching Rp 1,059.21 per share. While PT Timah Tbk. (TINS) has the lowest EPS value of Rp 54.96. In addition, it can also be concluded that in the period of 2013-2017, TLKM was the firm that had the smallest EPS data distribution, namely 16,278 and SMGR was the firm with the largest EPS data distribution, reaching 278.462.

Table 3

Descriptive Statistical Result of EPS (In Rupiah)

\begin{tabular}{|c|c|c|c|c|c|c|c|c|}
\hline \multirow[t]{2}{*}{ No. } & \multirow{2}{*}{$\begin{array}{l}\text { Firm } \\
\text { Code }\end{array}$} & \multicolumn{5}{|c|}{ Year } & \multirow[t]{2}{*}{ MEAN } & \multirow[t]{2}{*}{ STDEV } \\
\hline & & 2013 & 2014 & 2015 & 2016 & 2017 & & \\
\hline 1 & ADHI & 226.74 & 184.12 & 130.59 & 88.49 & 57.69 & 137.526 & 68.8414 \\
\hline 2 & BBRI & 865.22 & 982.67 & 1029.53 & 1061.88 & 1356.73 & 1059.206 & 182.275 \\
\hline 3 & BBNI & 482.52 & 578.2 & 486.18 & 608.02 & 730.16 & 577.016 & 101.976 \\
\hline
\end{tabular}




\begin{tabular}{lcccccccc}
4 & BMRI & 780.16 & 851.65 & 871.5 & 591.71 & 442.28 & 707.46 & 184.867 \\
5 & TLKM & 140.92 & 145.22 & 153.66 & 171.93 & 177.8 & 157.906 & 16.2783 \\
6 & SMGR & 905.37 & 938.35 & 762.28 & 762.3 & 246.09 & 722.878 & 278.462 \\
7 & PGAS & 435.56 & 370.78 & 242.58 & 168.67 & 80 & 259.518 & 145.032 \\
8 & TINS & 102.34 & 85.66 & 13.64 & 32.81 & 40.36 & 54.962 & 37.4115 \\
9 & WIKA & 101.69 & 122.1 & 114.32 & 135.01 & 151.18 & 124.86 & 19.0481 \\
10 & WSKT & 38.2 & 51.85 & 77.18 & 133.58 & 309.54 & 122.07 & 110.97 \\
& & & & & & 54.962 & 16.2783 \\
& MIN & & & & & & 1059.206 & 278.462 \\
\hline
\end{tabular}

Source: Summary of Firm Financial Statements, processed.

Table 4. shows that in the period of 2013-2017, PT Telekomunikasi Indonesia Tbk. (TLKM) is the firm with the best ROE that is equal to $25.45 \%$. This implies that TLKM was very effective in managing the fund from investors and turned them into the profits. TLKM is able to utilize $25.45 \%$ of the amount of money invested by investors to TLKM and it becomes the most effective firm among the other firms in the samples. While PT Timah Tbk. (TINS) is the firm that has the smallest ROE of $6.67 \%$. This explains why TINS could only utilize $6.67 \%$ of the amount of funds invested by investors to TINS and it becomes the firm with the lowest effectiveness compared to others.

Table 4

Descriptive Statistical Result of ROE

\begin{tabular}{|c|c|c|c|c|c|c|c|c|}
\hline \multirow[t]{2}{*}{ No. } & \multirow{2}{*}{$\begin{array}{l}\text { Firm } \\
\text { Code }\end{array}$} & \multicolumn{5}{|c|}{ Year } & \multirow[t]{2}{*}{ MEAN } & \multirow[t]{2}{*}{ STDEV } \\
\hline & & 2013 & 2014 & 2015 & 2016 & 2017 & & \\
\hline 1 & ADHI & $26.38 \%$ & $18.94 \%$ & $9.01 \%$ & $5.79 \%$ & $3.70 \%$ & $12.76 \%$ & 0.096 \\
\hline 2 & BBRI & $26.92 \%$ & $24.82 \%$ & $22.46 \%$ & $17.86 \%$ & $17.36 \%$ & $21.88 \%$ & 0.042 \\
\hline 3 & BBNI & $19.00 \%$ & $17.75 \%$ & $11.65 \%$ & $12.78 \%$ & $13.65 \%$ & $14.97 \%$ & 0.032 \\
\hline 4 & BMRI & $21.21 \%$ & $19.70 \%$ & $17.70 \%$ & $9.55 \%$ & $12.61 \%$ & $16.15 \%$ & 0.049 \\
\hline 5 & TLKM & $26.21 \%$ & $24.90 \%$ & $24.96 \%$ & $27.64 \%$ & $23.53 \%$ & $25.45 \%$ & 0.015 \\
\hline 6 & SMGR & $24.56 \%$ & $22.29 \%$ & $16.49 \%$ & $14.83 \%$ & $4.88 \%$ & $16.61 \%$ & 0.077 \\
\hline 7 & PGAS & $32.78 \%$ & $25.23 \%$ & $13.32 \%$ & $9.73 \%$ & $4.64 \%$ & $17.14 \%$ & 0.116 \\
\hline 8 & TINS & $10.53 \%$ & $11.38 \%$ & $1.89 \%$ & $4.45 \%$ & $5.10 \%$ & $6.67 \%$ & 0.041 \\
\hline 9 & WIKA & $19.35 \%$ & $15.08 \%$ & $12.93 \%$ & $9.51 \%$ & $9.27 \%$ & $13.23 \%$ & 0.042 \\
\hline 10 & WSKT & $15.44 \%$ & $17.59 \%$ & $10.80 \%$ & $10.81 \%$ & $18.46 \%$ & $14.62 \%$ & 0.037 \\
\hline
\end{tabular}


MIN

MAX
$6.67 \% \quad 0.015$

$25.45 \% \quad 0.116$

Source: Summary of Firm Financial Statements, processed.

In addition, it can also be concluded that in TLKM is the firm with the smallest data distribution of 0.015 and conversely, the National Gas Firm (Persero) Tbk. (PGAS) becomes the firm that has the biggest data distribution which is equal to 0.116 .

\section{Descriptive Statistical Result of Firm Value}

The indicator used to measure firm value was Tobin's Q. Table 5. presents the firm value of each firm in this study in the period of 2013-2017. The data were obtained from a summary of the firms' financial statements and the firms' annual financial statements that could be accessed at www.idx.co.id and an overview of the firms' financial statements that could be accessed through the official website of the respective firms.

Table 5. shows that PT Bank Negara Indonesia Tbk. (BBNI) has the lowest value of 1.0728 which means that its firm value on the IDX was relatively the same as the book value recorded in the firm. While PT Telekomunikasi Indonesia Tbk. (TLKM) has the highest value of 2.4352, which means that the firm value on the IDX was 2.4352 times greater than the book value recorded in the firm or this was what was called as overvalued. Table 5. also shows that PT Bank Rakyat Indonesia Tbk. (BBRI) has the smallest data distribution which is equal to 0.0475 and PT Semen Indonesia Tbk. (SMGR) has the largest data distribution which is equal to 0.7461 .

Table 5

Descriptive Statistical Result of Tobin's Q

\begin{tabular}{|c|c|c|c|c|c|c|c|c|}
\hline \multirow[t]{2}{*}{ No. } & \multirow{2}{*}{$\begin{array}{l}\text { Firm } \\
\text { Code }\end{array}$} & \multicolumn{5}{|c|}{ Firm Value } & \multirow[t]{2}{*}{ MEAN } & \multirow[t]{2}{*}{ STDEV } \\
\hline & & 2013 & 2014 & 2015 & 2016 & 2017 & & \\
\hline 1 & ADHI & 1.129 & 1.442 & 1.147 & 1.102 & 1.029 & 1.1698 & 0.1587 \\
\hline 2 & BBRI & 1.159 & 1.237 & 1.192 & 1.141 & 1.25 & 1.1958 & 0.0475 \\
\hline 3 & BBNI & 1.067 & 1.127 & 1.029 & 1.023 & 1.118 & 1.0728 & 0.0485 \\
\hline 4 & BMRI & 1.129 & 1.171 & 1.046 & 1.051 & 1.122 & 1.1038 & 0.0539 \\
\hline 5 & TLKM & 2.089 & 2.43 & 2.321 & 2.646 & 2.69 & 2.4352 & 0.2461 \\
\hline 6 & SMGR & 3.018 & 3.072 & 2.053 & 1.539 & 1.604 & 2.2572 & 0.7461 \\
\hline 7 & PGAS & 2.401 & 2.404 & 1.234 & 1.249 & 0.991 & 1.6558 & 0.6893 \\
\hline 8 & TINS & 1.401 & 1.344 & 0.819 & 1.246 & 1.076 & 1.1772 & 0.2352 \\
\hline 9 & WIKA & 1.515 & 2.107 & 1.605 & 1.269 & 0.984 & 1.496 & 0.4181 \\
\hline
\end{tabular}


10

WSKT

MIN

MAX
1.913

1.428

1.291

1.074

1.3756

$1.0728 \quad 0.0475$

$2.4352 \quad 0.7461$

Source: Summary of Firm Financial Statements, processed.

\section{Partial Least Square Result}

The first hypothesis examines the effect of CG on the corporate financial performance. The results show that statistically, the P-value of the influence of CG on the corporate financial performance showed 0.032 which means that it is significant and the positive number indicates the influence that occurs between these variables is a positive influence. This is because it is still below the significance level of 5\% (0.05), therefore H1 is supported. Thus, it can be concluded that the firm with the maximum implementation of CG could improve the corporate financial performance, which in this case would be reflected in the firm's ROE and EPS. This was consistent with what was expressed by Paul (2015) who revealed that the implementation of CG would create control and supervision that made the corporate finance more effective and prevented corporate scandals, bankruptcies and risk differences. Nahar et al. (2016) revealed that the implementation of CG made the firm more consolidated because the existing board of directors aimed to maximize the corporate financial performance. Overall, this finding consistent with Aras et al. (2010); Bastomi et al. (2017); Mai (2017); Orazalin et al. (2016); Suhardjanto et al. (2018).

The second hypothesis examines the effect of $\mathrm{CG}$ on firm value. The results show that statistically, the P-Value is 0.073 which means that it is significant at $10 \%$ level of significance. Therefore, $\mathrm{H} 2$ is accepted. This is consistent with the research conducted by Bhat et al. (2018); Handriani and Robiyanto (2019); Isshaq et al. (2009) which stated that there was direct influence between $\mathrm{CG}$ and firm value.

Table 6

Partial Least Square Result

\begin{tabular}{clccl}
\hline No. & \multicolumn{1}{c}{ Hypothesis } & P-Values & Significance & Conclusion \\
\hline 1 & CG à Firm Financial Performance & 0.032 & $5 \%$ & Significant \\
2 & CG à Firm Value & 0.073 & $10 \%$ & Significant \\
3 & IC à Firm Financial Performance & 0.084 & $10 \%$ & Significant \\
4 & IC à Firm Value & 0.042 & $5 \%$ & Significant \\
5 & Firm Financial Performance à Firm Value & 0.004 & $5 \%$ & Significant \\
\hline
\end{tabular}

Source: Summary of Firm Financial Statements, processed. 
The third hypothesis examines the influence of IC on the corporate financial performance. The results show that statistically, the P-Value is 0.084 which means that it is significant at $10 \%$ level of significance. Therefore, H3 is accepted. This is in line with the results found by Fathi et al. (2013); Kamukama et al. (2010); Ousama and Fatima (2015); Sidharta and Affandi (2016) which claimed that IC could develop the corporate financial performance. Therefore, when an IC of the firm increased, the corporate financial performance would also increase and vice versa.

The fourth hypothesis examines the influence of IC on firm value. The results indicate that statistically, the P-Value is 0.042 which means that it is significant. This is because the value is below the significance level of $5 \%$ (0.05). A positive value indicates that the influence occurs between IC and firm value is a positive influence. This is similar to what was conveyed by Sudibya, Arun, and Restuti (2014) who stated that if the IC was managed efficiently, it would create added value for the firm. They also added that when the firm had added value, it would be able to compete with other firms and get good value from investors. Other research conducted by Anifowose et al. (2017); Sardo and Serrasqueiro (2017) explained that IC had a positive influence on firm value. This, at the same time, proved that $\mathrm{IC}$ was indeed a driver of the firm value.

The fifth hypothesis examines the effect of financial performance on firm value. The results show that statistically, the P-Value is significant which reaches 0.004 . This is because the value is still below the significance level of $5 \%(0.05)$. This positive value indicates that the influence that occurs between the corporate financial performance and firm value is a positive influence. This is similar to what was conveyed by Mai (2017) who supported that there was a positive influence between corporate financial performance and firm value with ROE and EPS as the indicators. ROE is a ratio that could measure the firm effectiveness in managing its finances by using funds invested by investors. The greater the ROE value, the more the profit and its effectiveness which would be considered by investors. EPS was used as an indicator of a corporate financial performance because it is a ratio that can calculate the profit shared to investors based on the funds invested. The higher the EPS, the more attractive the firms for other investors to invest in the firm. Research by Handriani and Robiyanto (2018) also supported the results of this study which also explained that the corporate financial performance had a significant positive effect on firm value. 
Table 7

The Result of Hausman-Test

\begin{tabular}{lccc}
\hline \multicolumn{4}{c}{ CG + IC à Firm Financial Performance } \\
\hline & Chi-Sq. & DF & P-Values \\
& Statistic & & \\
Cross-section random & 0.424271 & 2 & 0.8089 \\
Period random & 0.388643 & 2 & 0.8234 \\
Cross-section and period random & 0.250905 & 2 & 0.8821 \\
\hline \multicolumn{4}{c}{ Firm Financial Performance à Firm Value } \\
\hline \multicolumn{5}{c}{ Chi-Sq. } & DF & P-Values \\
& Statistic & & \\
Cross-section random & 0.132995 & 1 & 0.7153 \\
Period random & 0.035227 & 1 & 0.8511 \\
Cross-section and period random & 0.003114 & 1 & 0.9555 \\
\hline
\end{tabular}

Source: Summary of Firm Financial Statements, processed.

In general, this study found that CG was able to positively influence the firm value with financial performance as the intervening variable. Furthermore, this research proved that IC had a direct positive impact on the firm value compared to using intervening variables. To check the robustness of the results of this study, endogeneity test has been conducted by using the Hausman-Test for two equations used. If the probability values higher than 5\%, so the Hausman-Test results shows that no endogeneity problem existed. The result of Hauman-Test can be seen in Table 7 . The result shows that no endogeneity problem existed in both models.

\section{Conclusion}

The analysis of the effects of CG, IC, corporate financial performance and the firm value of the firms in the SRI-Kehati index in the period of 2013-2017 was carried out by using the data collected from the annual financial statements of the firms. The results of this study indicated that there was a significant positive effect between $\mathrm{CG}$ and IC toward the financial performance. The study also found that an increase in IC would affect the corporate financial performance and also would directly increase the firm value. Therefore, the better the implementation of CG and IC management in a firm, the better the corporate financial performance which would be reflected in ROE and EPS. Increasing financial performance of this firm would also make the firm value to increase. 
The firm managers should begin to pay attention to the existed intangible assets of the firm. This is because not only tangible assets can bring benefits, but intangible assets can also increase profits for the firm. The intangible asset referred to in this study is the IC. Furthermore, the firm manager must also apply a good CG to the firm because it enables the firm to improve the corporate financial performance and firm value which can attract the attention of the investors to invest their funds in the firm concerned. GCG will also be able to increase the confidence of investors to increase their investment in the firm.

This research present research was still specifically conducting studies on firms categorized as socially responsible firms. Future researches are suggested to make comparisons on the firms categorized as socially responsible and those that have not yet included in the category. Although the sample size in this study relative small, but it can fulfil the 10-times rule. Unfortunately, the sample size still small enough to fulfil the newer sample size determination rules i.e. the inverse square root and the gamma-exponential method. Based on this, so researcher must consider to enlarge their sample size in the next studies. Researches in other capital markets are also highly recommended.

\section{References}

Abdulazeez, N., \& Mercy. (2016). Corporate Governance and Financial Performance of Listed Deposit Money Banks in Nigeria. Journal of Accounting \& Marketing, 6(1). doi: https://doi.org/10.4172/2168-9601.1000153

Adefemi, F., Hassan, A., \& Fletcher, M. (2018). Corporate governance disclosure in Nigerian listed companies. International Research Journal of Business Studies, 11(2), 67-80. doi: https://doi.org/10.21632/irjbs.11.2.67-80

Adeusi, S. O., Akeke, N. I., Aribaba, F. O., \& Adebisi, O. S. (2013). Corporate Governance and Firm Financial Performance : Do Ownership and Board Size Matter. Academic Journal of Interdisciplinary Studies, 2(3). doi:http://dx.doi.org/10.5901/ajis.2013.v2n3p251

Al-Musali, M. A. K., \& Ismail, K. N. I. K. (2014). Intellectual Capital and Its Effect on Financial Performance of Banks : Evidence from Saudi Arabia. Procedia - Social and Behavioral Sciences, 164, 201-207. doi: https://doi.org/10.1016/j.sbspro.2014.11.068

Al-Najjar, B. (2018). Corporate governance and audit features: SMEs evidence. Journal of Small Business and Enterprise Development, 25(1), 163-179. doi:https://doi.org/10.1108/ JSBED-08-2017-0243

Andriana, A., \& Panggabean, R. R. (2017). The Effect of Good Corporate Governance and Environmental Performance on Financial Performance of the Proper Listed Company on Indonesia Stock Exchange. Binus Business Review, 8(1), 1. doi: https://doi.org/10.21512/ bbr.v8i1.1757 
Anifowose, M., Abdul Rashid, H. M., \& Annuar, H. A. (2017). Intellectual capital disclosure and corporate market value: does board diversity matter? Journal of Accounting in Emerging Economies, 7(3), 369-398. doi: https://doi.org/10.1108/jaee-06-2015-0048

Aras, G., Aybars, A., \& Kutlu, O. (2010). Managing corporate performance. International Journal of Productivity and Performance Management, 59(3), 229-254. doi: https://doi. org/10.1108/17410401011023573

Arifin, J., Suhadak, Astuti, E. S., \& Arifin, Z. (2014). The Influence of Corporate Governance, Intellectual Capital on Financial Performance and Firm Value of Bank Sub-Sector Companies Listed at Indonesia Stock Exchange in Period 2008-2012. European Journal of Business and Management, 26, 159-169.

Bastomi, M., Salim, U., \& Aisjah, S. (2017). The Role of Corporate Governance and Risk Management on Banking Financial Performance in Indonesia. Jurnal Keuangan dan Perbankan, 21(4), 670-680. doi: https://doi.org/10.26905/jkdp.v21i4.1285

Bhat, K. U., Chen, Y., Jebran, K., \& Bhutto, N. A. (2018). Corporate governance and firm value: a comparative analysis of state and non-state owned companies in the context of Pakistan. Corporate Governance: The International Journal of Business in Society, 18(6), 1196-1206. doi:https://doi.org/10.1108/CG-09-2017-0208

Brahmana, R. K., Brahmana, R. K., \& Ho, T. C. F. (2018). Training and Development Policy, Corporate Governance, and Firm Performance. Gadjah Mada International Journal of Business, 20(1), 59-87. doi:https://doi.org/10.22146/gamaijb.12995

Cantu, F. J., Bustani, A., Molina, A., \& Moreira, H. (2009). A Knowledge-Based Development Model : The Research Chair Strategy. Journal of Knowledge Management, 13(1), 154-170. doi: https://doi.org/10.1108/13673270910931233

Cater, T., \& Cater, B. (2009). Tangible Resources as Antecedents of a Company's Competitive Advantage and Performance. Journal for East European Management Studies., 14(2), 186-209. https://www.jstor.org/stable/23281130

Chen, M. C., Cheng, S. J., \& Hwang, Y. (2005). An empirical investigation of the relationship between intellectual capital and firms' market value and financial performance. Journal of Intellectual Capital, 6(2). doi:https://doi.org/10.1108/14691930510592771

Ehikioya, B. I. (2009). Corporate Governance Structure and Firm Performance in Developing Economics : Evidence from Nigeria. Corporate Governance: International Journal Business and Social, 9, 231-243. doi: https://doi.org/10.1108/14720700910964307

Fathi, S., Farahmand, S., \& Khorasani, M. (2013). Impact of Intellectual Capital on Financial Performance. International Journal of Academic Research in Economics and Management Sciences, 2(1).

Flore, B. (2000). A Resource Based Approach to Performance and Competition : An Overview of The Connections Between Resources And Competition.

Gamayuni, R. R. (2015). The Effect of Intangible Asset, Financial Performane and Financial Policies on the Firm Value. International Journal of Scientific \& Technology Research, 4(1). http://www.ijstr.org/final-print/jan2015/The-Effect-Of-Intangible-Asset-Finan- 
cial-Performance-And-Financial-Policies-On-The-Firm-Value.pdf

Ganescu, M. C., \& Gangone, A. D. (2012). A Methodology for Measuring Responsible Corporate Governance in Countries of Emerging Europe. The USV Annals of Economics and Public Administration, 12(16).

Hair, J. F., Black, W. C., Babin, B. J., \& Anderson, R. E. (2009). Multivariate Data Analysis (7 ed.): Pearson.

Handriani, E., \& Robiyanto, R. (2018). Corporate Finance and Firm Value in The Indonesian Manufacturing Companies. International Research Journal of Business Studies, 11(2), 113-127. doi:https://doi.org/10.21632/irjbs.11.2.113-127

Handriani, E., \& Robiyanto, R. (2019). Institutional ownership, independent board, board size, and firm performance: evidence from Indonesia. Contaduría y Administración, 64(3), e118. doi:http://dx.doi.org/10.22201/fca.24488410e.2018.1849

Hassan, M. K., \& Halbouni, S. S. (2013). Corporate Governance, Economic Turbulance and Financial Performance of UAE Listed Firms. Studies in Economics and Finance, 30(2). doi: https://doi.org/10.1108/10867371311325435

Hermawan, S., \& Herlina, S. (2013). Studi Interpretatif Identifikasi dan Interaksi Intellectual Capital Terhadap Kinerja Perusahaan. Jurnal Review Akuntansi dan Keuangan, 3(1). doi: https://doi.org/10.22219/jrak.v3i1.1466

Hossein, S. R., \& Zivar, B. (2014). The Impact of Intellectual Capital on The Financial Performance of Listed Companies in Tehran Stock Exchange. International Journal of Academic Research in Accounting, Finance, and Management Sciences, 4(1), 119-127.

Isshaq, Z., Bokpin, G., \& Onumah, J. M. (2009). Corporate Governance, Ownership Structure, Cash Holdings, and Firm Value on the Ghana Stock Exchange. Journal of Risk Finance, 10(5). doi: https://doi.org/10.1108/15265940911001394

Jaffar, R., Aziendeh, R. R., Shukor, Z. A., \& Rahman, M. R. C. A. (2018). Environmental Performance: Does Corporate Governance Matter? Jurnal Pengurusan, 52, 133-143. http://ejournal.ukm.my/pengurusan/article/view/21546

Kamath, B. (2015). Impact of Intellectual Capital on Financial Performance and Market Valuation of Firms in India. International Letters of Social and Humanistic Sciences, 48(2). doi: https://doi.org/10.18052/www.scipress.com/ILSHS.48.107

Kamukama, N., Ahiauzu, A., \& Ntayi, J. (2010). Intellectual Capital and Financial Performance in Uganda's Microfinance Institutions. African Journal of Accounting, Economics, Finance, and Banking Research, 6(6).

Khanqah, V. T., Khosroshahi, M. A., \& Ghanavati, E. (2012). An Empirical Investigation of The Impact of Intellectual Capital on Firms Market Value and Financial Performance: Evidence from Iranian Companies. International Journal Management, 2(1).

Kock, N. (2018). Minimum Sample Size Estimation in PLS-SEM: An Application in Tourism and Hospitality Research. In Applying Partial Least Squares in Tourism and Hospitality Research. Ali, F., Rasoolimanesh, S.M. and Cobanoglu, C. (Ed.), Emerald Publishing Limited, 1-16. doi: https://doi.org/10.1108/978-1-78756-699-620181001 
Kock, N., \& Hadaya, P. (2018). Minimum sample size estimation in PLS-SEM: The inverse square root and gamma-exponential methods. Information Systems Journal, 28(1), 227 261. doi: https://doi.org/10.1111/isj.12131

Komnenic, B., \& Pokrajcic, D. (2012). Intellectual Capital and Corporate Performance of MNCs in Serbia. Journal of Intellectual Capital, 13(1). doi: https://doi. org/10.1108/14691931211196231

Kuo, A., Kao, M.-S., \& Sakolvieng, N. (2019). On new ventures' board of directors: Formation, adjustment, and influences on internationalization. ABAC Journal, 39(2), 23-44.

Lakaba,A., \& Robiyanto, R. (2018). Evaluasi kinerja saham bertanggungjawab sosial (Studi pada saham-saham yang masuk perhitungan indeks SRI-Kehati). Jurnal Organisasi Dan Manajemen, 14(2), 94-106. doi:https://doi.org/10.20885/vol14ino2pp94-106.

Mai, M. U. (2010). Impact Of Dividend Policy On Company Value In Manajerial Oportunistic Behavioral Conduct And Corporate Governance Structure Empirical Study on Manufacturing Companies Go Public In Indonesian Capital Market. (Dissertation), Universitas Diponegoro, Semarang, Indonesia.

Mai, M. U. (2017). Mediation of CSR and Profitability on the Influences of GCG Mechanism to the Firm Value. Jurnal Keuangan dan Perbankan, 21(2), 253-264.

Marlina, T. (2013). Pengaruh Earning Per Share, Return On Equity, Debt To Equity Ratio Dan Size Terhadap Price To Book Value. Jurnal Ilmiah Akuntansi, 1(1).

Marr, B., Gray, D., \& Neely, A. (2003). Why Do Firms Measure Their Intellectual Capital? Journal of Intellectual Capital, 4(4).

Melo, T. (2012a). Determinants of corporate social performance: the influence of organizational culture, management tenure and financial performance. Social Responsibility Journal, 8(1), 33-47. doi: https://doi.org/10.1108/17471111211196557

Melo, T. (2012b). Slack $\square$ resources hypothesis: a critical analysis under a multidimensional approach to corporate social performance. Social Responsibility Journal, 8(2), 257-269. doi: https://doi.org/10.1108/17471111211234879

Mukhtaruddin, Relasari, \& Felmania, M. (2014). Good Corporate Governance Mechanism, Corporate Social Responsibility Disclosure on Firm Value: Empirical Study on Listed Company in Indonesia Stock Exchange. International Journal of Finance and Accounting Studies, 2(1), 1-10. doi: https://doi.org/10.7575/aiac.ijfas.v.2n.1p.1

Nahar, S., Jubb, C., \& Azim, M. (2016). Risk Governance and Performance : A Developing Country Perspective. Managerial Auditing Journal, 31(3). doi: https://doi.org/10.1108/ MAJ-02-2015-1158

Nuryaman. (2015). The Influence of Intellectual Capital on the Firm's Value with the Financial Performance as Intervening Variable. Procedia - Social and Behavioral Sciences, 211(1). doi: https://doi.org/10.1016/j.sbspro.2015.11.037

Onakoya, A., Ofoegbu, D. I., \& Fasanya, I. (2012). Corporate Governance and Bank Performace : A Pooled Study of Selected Banks in Nigeria. European Scientific Journal, 28(8). doi: https://doi.org/10.19044/esj.2012.v8n28p\%25p 
Orazalin, N., Mahmood, M., \& Lee, K. J. (2016). Corporate Governance, Financial Crises and Bank Performance : Lessons from Top Russian Banks. International Journal of Business and Society, 16(5).

Ousama, A. A., \& Fatima, A. H. (2015). Intellectual capital and financial performance of Islamic banks. International Journal of Learning and Intellectual Capital, 12(1).

Patthirasinsiri, N., \& Wiboonrat, M. (2017). Measuring intellectual capital of science park performance for newly established science parks in Thailand. Kasetsart Journal of Social Sciences. doi: https://doi.org/10.1016/j.kjss.2017.10.001

Paul, G. D. (2015). Impact of Corporate Governance on Financial Performance of Microfinance Banks in North Central Nigeria. International Journal of Humanities Social Sciences and Education, 2(2).

Prusty, T., \& Kumar, S. (2016). Effectivity of Corporate Governance on Financial Performance of IT Companies in India with Special Reference to Corporate Board. Amity Journal of Corporate Governance, 1(1).

Pulic, A. (2000). MVA and VAIC Analyis of Randomly Selected Companies from FTSE 250.

Ratri, R. F., \& Dewi, M. (2017). The Effect of Financial Performance and Environmental Performance on Firm Value with Islamic Social Reporting (ISR) Disclosure as Intervening Variable in Companies Listed at Jakarta Islamic Index (JII). Paper presented at the The 17th Annual Conference of the Asian Academic Accounting Association (2016 FourA Conference).

Riahi $\square$ Belkaoui, A. (2003). Intellectual capital and firm performance of US multinational firms: A study of the resource $\square$ based and stakeholder views. Journal of Intellectual Capital, 4(2), 215-226. doi:https://doi.org/10.1108/14691930310472839

Robiyanto, R. (2018). Performance Evaluation of Stock Price Indexes in the Indonesia Stock Exchange. International Research Journal of Business Studies, 10(3), 173-182. doi:https://doi.org/10.21632/irjbs.10.3.173-182

Robiyanto, R., Anggraeni, A. D., Nugraha, A. K. N. A., \& Lako, A. (2019). The Effect of Good Corporate Governance Mechanism on Firm Value of Indonesian Socially Responsible Firms. Quality: Access to Success, 20(173), 59-63.

Sardo, F., \& Serrasqueiro, Z. (2017). A European empirical study of the relationship between firms' intellectual capital, financial performance and market value. Journal of Intellectual Capital, 18(4), 771-788. doi: https://doi.org/10.1108/JIC-10-2016-0105

Sidharta, I., \& Affandi, A. (2016). The empirical study on intellectual capital approach toward financial performance on rural banking sectors in Indonesia. International Journal of Economics and Financial Issues, 6(3), 1247-1253.

Siminica, M., Ionascu, C., \& Sichigea, M. (2019). Corporate Social Performance versus Financial Performance of the Romanian Firms. Prague Economic Papers, 28(1), 49-69. doi: https://doi.org/10.18267/j.pep.687

Sudibya, Arun, D. C. N., \& Restuti, M. D. (2014). Pengaruh Modal Intelektual terhadap Nilai Perusahaan dengan Kinerja Keunagan sebagai Variabel Intervening. BENEFIT Jurnal 
Manajemen dan Bisnis, 18(1). doi: https://doi.org/10.23917/benefit.v18i1.1390

Suhardjanto, D., Purwanto, P., Sari, K., \& Setiany, E. (2018). Corporate governance and social disclosure: a comparative study of listed hospitality industries in South East Asia International Journal of Trade and Global Markets, 11(1/2), 21-30. doi:https://doi. org/10.1504/IJTGM.2018.092495

Suparno, \& Ramadini, R. (2017). Pengaruh Intellectual Capital dan Earning PerShare terhadap Nilai Perusahaan di Bursa Efek Indonesia Periode 2010-2014. Jurnal Manajemen dan Keuangan, 6(1).

Tuan, N. V., \& Tuan, N. A. (2016). Corporate Governance Structures And Performance Of Firms In Asian Markets: A Comparative Analysis Between Singapore And Vietnam. Organizations and Markets in Emerging Economies, 7(2), 112-140. doi: https://doi. org/10.15388/omee.2016.7.2.14210

Ueasangkomsate, P., \& Jangkot, A. (2017). Enhancing the innovation of small and medium enterprises in food manufacturing through Triple Helix Agents. Kasetsart Journal of Social Sciences . doi: https://doi.org/10.1016/j.kjss.2017.12.007

Utomo, M. N., Wahyudi, S., Muharam, H., \& Taolin, M. L. (2018). Strategy to improve firm performance through operational efficiency commitment to environmental friendlines: Evidence from Indonesia. Organizations and Markets in Emerging Economies, 9(1), 6285. doi: https://doi.org/10.15388/omee.2018.10.00004

Vintila, G., \& Ghergina, S. C. (2012). An Empirical Investigation of the Relationship between Corporate Governance Mechanisms, CEO Characteristics and Listed Companies. International Business Research, 10(5). doi: https://doi.org/10.5539/ibr.v5n10p175

Wahyudi, S., Pangestuti, I. R. D., Laksana, R. D., Hersugondo, H., \& Robiyanto, R. (2018). Corporate social responsibility on SKI KEHATI index corporate performance: A case study. International Journal of Economics and Business Administration, 6(4), 93-104.

Zulkafli, A. H., Ahmad, Z., \& M., E. E. (2017). The Performance of Socially Responsible Investments in Indonesia: A Study of the Sri Kehati Index (SKI). Gadjah Mada International Journal of Business, 19(1), 59-76. doi:https://doi.org/10.22146/gamaijb.17959 